INTERNATIONAL JOURNAL OF RESEARCHES IN BIOSCIENCES, AGRICULTURE AND TECHNOLOGY (C) VISHWASHANTI MULTIPURPOSE SOCIETY (Global Peace Multipurpose Society) R. No. MH-659/13(N) www.vmsindia.org

\title{
EFFECTS OF VARIOUS SMS COMPOST INPUTS ON THE GROWTH AND YIELD OF CHICK PEA (CICER ARIETINUM)
}

\author{
A. S. Rathod and A. S. Deshmukh
}

Matoshree Vimalabai Deshmukh Mahavidyalaya, Amravati

\begin{abstract}
:
Unused agro waste is converted into value added products such as gourmet and medicinal mushroom and the spent mushrooms substrate composted. In this study, SMS is composted along with the karanj seed cake waste and flyash and applied to Cicer aerietinum. The physical parameters, germination time, protein contents were observed. Compost with addition of karanj seed cake waste proved to be best for growth of Ciceraerietinum followed by fly ash compost than plain compost. Plain soil without compost supplementation had lowest results. Keywords: Mushroom, Agro waste, substrate, Compost, Karanj, Fly ash.
\end{abstract}

\section{Introduction:}

The huge quantity of spent mushroom substrate (SMS) generation has created critical disposal problem, challenge to mushroom industry and also environmental pollution problem. During SMS weathering process, leachate containing high concentration of dissolved organic matter and inorganic salts is released into underlying soils (Mingxin et al., 2001). It may be channelized as nutrients to the plants through composting. Karanj seed cake is rich in proteins $(30-35 \%)$ but is unpalatable to cattle even at $4 \%$ level due to the presence of toxic principles (Karanjin, Pongamol etc). These toxins are removed during solvent extraction. Their disposal is also a great problem. They can be used in compound cattle feed. The Karanj seed cake has been reported as organic manure. The total fly ash production in India is estimated 2-3 times more than other countries (Gupta and Birendra, 1998). Flyash is disposed in the surrounding water and soils, resulting in the huge environmentally ecological problem. The use of flyash is found to increase the crop yields and is also capable to improve the physicochemical characteristics of soil (Hill and Lamp, 1980; Khan et al., 1996; Sarangi and Mishra, 1998). In the present investigation, the spent mushroom substrate is composted in combination with Karanj seed cake waste after biodiesel extraction and fly ash. The compost sets are applied to chickpea for increasing the crop yield. Thus, useful for environmental protection also.

\section{Material and Method :}

The composition of compost using spent mushroom substrate i.e. Wheat (Triticum aestivum), Mung (Phaseolus radiatus), Soybean (Glycine max), Toor (Cajanus cajan) and their combination is as shown in Table 1 . They were prepared in different sets in seven different pits of $30 \mathrm{~cm} \times 30 \mathrm{~cm} \times 30 \mathrm{~cm}$. Watering was done at regular interval of 2-3 days to maintain moisture and mixed by separate wood sticks.

Pot experiment was conducted. For pot experiment the soil was dried, crushed and sieved and was filled in earthenware pots $(4 \mathrm{~kg}$ per pot). Compost from each set (I - VII) was applied $(10 \%$ of soil weight) to the soil in separate pots and soil wetted with water. Seven seeds were sown in each pot for every treatment. Each set was taken in three replicates and its effect on crop was analysed comparatively within growth period of 60 days. Protein content in the seed was also recorded by Bradford method (1976).

\section{Result and Discussion:}

The results from Table 2 show that the highest germination percentage was observed by adding karanj compost $\left(\mathrm{T}_{6}, 90.47 \%\right)$, followed by flyash compost $\left(\mathrm{T}_{3}, 80.94 \%\right)$ as compared to control. Prasad et al., 2000 reported similar type of findings by fly ash amendments in acid loam and calcareous soil for the crops Vagna radiata and Pisum sativum. Plant height was influenced significantly by different treatments. The lowest height $(22.22 \mathrm{~cm})$ was recorded where no compost was applied. The highest plant height $(31.05 \mathrm{~cm})$ was observed in $\mathrm{T}_{6}$ set. Ahlawat et al., 2007 treated the wheat crop with SMS (recomposted by different methods and mixed with arable soil alone and in combination with chemical fertilizers). The plant height varied between 53.00 to $86.00 \mathrm{~cm}, 50.60$ to $79.50 \mathrm{~cm}$ and 42.25 to $58.75 \mathrm{~cm}$ respectively. M. Kubilay Onal and Bulent Topcuoglu studied the effect of spent mushroom compost on the dry matter and mineral content of pepper. The best results for yield as regard to productivity was obtained at 30 ton/ha SMC application. At 60 ton/ha SMC application pepper yield was depressed due to high salt content. This research showed that SMC could be applied in green house soil at agronomic rates without heavy metal and 
salinity defects. Thomas Ebertseder et al., 2001 reported that application of compost could improve the quality of plant. Application of compost could increase the amount of crude protein from $10.6 \%$ up to $13.21 \%$.

In the present study, it was observed that appearance of flowers was enhanced by compost application. As shown in Table 3, there is $14 \%$ increase in number of seeds in case of plants treated with Karanj compost $\left(\mathrm{T}_{5}, \mathrm{~T}_{6}\right)$ as compared to flyash compost $\left(\mathrm{T}_{2}, \mathrm{~T}_{3}\right)$. The total gm \% of protein was highest in seeds of plant grown in compost of karanj seed cake ( $\mathrm{T}_{6}$, $56.70 \%)$ followed by flyash compost $\left(\mathrm{T}_{3}, \mathrm{~T}_{4}\right.$ and $\left.\mathrm{T}_{2}\right)$. The protein contents $\left(\mathrm{T}_{8}, 38.33 \%\right)$ was found to be less in plain soil treatment. The total fresh and dry weight of seeds was found to be highest in set $\mathrm{T}_{5}$ (Karanj seed compost).

Table. 1: Composition of compost.

\begin{tabular}{|l|l|l|l|l|l|}
\hline Set & SMS & Dung & Urine & Flyash & Karanj Seed Cake \\
\hline I & $900 \mathrm{gm}$ & $450 \mathrm{gm}$ & $150 \mathrm{gm}$ & - & - \\
\hline $\mathrm{II}$ & $900 \mathrm{gm}$ & $450 \mathrm{gm}$ & $150 \mathrm{gm}$ & $150 \mathrm{gm}$ & - \\
\hline $\mathrm{III}$ & $900 \mathrm{gm}$ & $450 \mathrm{gm}$ & $150 \mathrm{gm}$ & $300 \mathrm{gm}$ & - \\
\hline $\mathrm{IV}$ & $900 \mathrm{gm}$ & $450 \mathrm{gm}$ & $150 \mathrm{gm}$ & $600 \mathrm{gm}$ & - \\
\hline V & $900 \mathrm{gm}$ & $450 \mathrm{gm}$ & $150 \mathrm{gm}$ & - & $150 \mathrm{gm}$ \\
\hline VI & $900 \mathrm{gm}$ & $450 \mathrm{gm}$ & $150 \mathrm{gm}$ & - & $300 \mathrm{gm}$ \\
\hline VII & $900 \mathrm{gm}$ & $450 \mathrm{gm}$ & $150 \mathrm{gm}$ & - & $600 \mathrm{gm}$ \\
\hline
\end{tabular}

Table. 2: Effect of different compost treatment on germination and growth of chickpea.

\begin{tabular}{|l|l|l|l|l|}
\hline \multirow{2}{*}{ Treatment } & \multirow{2}{*}{ Germination (\%) } & \multicolumn{3}{|l|}{ Physical character } \\
\cline { 3 - 5 } & & Ht (cm) & Branches No. & Leaves No. \\
\hline $\mathrm{T}_{1}$ & 71.42 & 26.31 & 3.00 & 8.33 \\
\hline $\mathrm{T}_{2}$ & 66.66 & 29.77 & 3.00 & 8.66 \\
\hline $\mathrm{T}_{3}$ & 80.94 & 29.13 & 2.33 & 8.33 \\
\hline $\mathrm{T}_{4}$ & 71.42 & 27.30 & 3.33 & 8.33 \\
\hline $\mathrm{T}_{5}$ & 76.18 & 28.36 & 3.66 & 13.33 \\
\hline $\mathrm{T}_{6}$ & 90.47 & 31.06 & 5.00 & 14.66 \\
\hline $\mathrm{T}_{7}$ & 80.95 & 26.11 & 3.00 & 11.66 \\
\hline $\mathrm{T}_{8}$ & 66.66 & 22.24 & 2.00 & 8.33 \\
\hline
\end{tabular}

Table. 3: Effects of different compost treatments on No. of days required for initiation of flower and yield of chick pea.

\begin{tabular}{|c|c|c|c|c|c|c|}
\hline \multirow[b]{2}{*}{ Treatment } & \multirow{2}{*}{$\begin{array}{c}\text { No. of days } \\
\text { required for } \\
\text { initiation of } \\
\text { flower }\end{array}$} & \multirow[b]{2}{*}{$\begin{array}{l}\text { No. of Pods } \\
\text { per plant }\end{array}$} & \multirow[b]{2}{*}{$\begin{array}{c}\text { No. of seed } \\
\text { per plant }\end{array}$} & \multicolumn{2}{|c|}{ Yield } & \multirow[b]{2}{*}{$\begin{array}{c}\text { Protein } \\
(\%)\end{array}$} \\
\hline & & & & $\begin{array}{l}\text { Fresh } \\
\text { Wt }\end{array}$ & $\begin{array}{l}\text { Dry } \\
\text { wt }\end{array}$ & \\
\hline $\mathrm{T}_{1}$ & 45.66 & 4.33 & 17.33 & 16.15 & 9.32 & 41.30 \\
\hline $\mathrm{T}_{2}$ & 37.66 & 5.33 & 17.66 & 16.22 & 10.88 & 44.27 \\
\hline $\mathrm{T}_{3}$ & 43.00 & 3.33 & 14.33 & 17.04 & 9.89 & 47.82 \\
\hline $\mathrm{T}_{4}$ & 43.00 & 4.33 & 15.66 & 13.57 & 9.33 & 46.63 \\
\hline $\mathrm{T}_{5}$ & 38.66 & 4.66 & 19.00 & 18.08 & 11.06 & 43.49 \\
\hline $\mathrm{T}_{6}$ & 32.66 & 5.66 & 22.00 & 24.01 & 11.45 & 56.70 \\
\hline $\mathrm{T}_{7}$ & 38.00 & 4.66 & 15.00 & 14.57 & 9.97 & 46.03 \\
\hline $\mathrm{T}_{8}$ & 48.66 & 3.33 & 4.66 & 2.57 & 1.52 & 38.33 \\
\hline
\end{tabular}

\section{Conclusion:}

The huge quantity of spent mushroom substrate can be converted into environment friendly compost with high nutritional qualities for soil conditioning and also for enhancement of crop yield as a need of hour. It can be suggested that the spent mushroom composted with karanj seed cake waste will give rise to value added product. The compost set $\mathrm{T}_{5}$ and $\mathrm{T}_{6}$ enhance the yield as well as protein content in Cicer arietinum in pot experiment. From the above result the karanj seed compost is found more effective than flyash and control compost.

\section{References:}

Ahlawat, O.P., M.P. Sagar, Dev Raj, Pardeep Gupta and B. Vijay (2007). Effect of recomposted button mushroom spent substrate on the yield of wheat. Mushroom Research 16(1) : 41-46. 
Bradford, M.M. (1976). A rapid and sensitive method for the quantitation of microgram quantities of protein utilizing the principle of protein-dyebinding. Anal. Biochem. 72 : 248254.

Ebertseder Thomas, Guster Reinhold (2001). Nutrition potential of biowaste composts In : Applying composts Benefits and Needs Seminar Proceedings Brussels : 22-23.

Gupta, A. and Birendra, K. (1998). Environmental impact and leaching characteristics of fly ash obtained from thermal power station. Res. J. Chem. Environ. 2 : 23-28.

Hill, M.J. and Lamp, C.A. (1980). Use of pulverized fuel ash Victorian brown coal as a source of nutrients for a pasture species. Aust. J. Exptl. Agric. Animal Husb. 20 : 377-384.

Khan, S.U., Begum, T. and Singh, J. (1996). Effect of fly ash on physicochemical properties and nutrient status of soil. Ind. J. Environ. Hlth. $8: 41-46$.

Kubilay, M. ONAL, Bulent-TOPCUOGLU. The effect of spent mushroom compost on the dry matter and mineral content of pepper (Piper nigrum) grown in green house.

Mingxin G., Jon C. and R.H. Fox (2001). Effects of spent mushroom substrate weathering on the chemistry of underlying soils. Journal of Environmental Quality 30 : 2127-2134.

Prasad, B.K., S.K. Banerjee and H. Roy (2000). Effect of fly ash amendment on germination behavior and seeding survival on certain cultivated legumes. Environment and Ecology. 18(1) : 210-216.

Sarangi, P.K. and Mishra, P.C. (1998). Soil metabolic activities and yield in ground nut, ladies finger and radish in fly ash amended soil. Res. J. Chem. Environ. 2 : 7-13. 